\title{
PDX1 wt Allele
}

National Cancer Institute

\section{Source}

National Cancer Institute. PDX1 wt Allele. NCI Thesaurus. Code C118248.

Human PDX1 wild-type allele is located in the vicinity of 13q12.1 and is approximately $6 \mathrm{~kb}$ in length. This allele, which encodes pancreas/duodenum homeobox protein 1, is involved in transcriptional regulation of insulin and other pancreatic genes. Mutation of the gene is associated with pancreatic agenesis, susceptibility to early-onset insulin-dependent diabetes mellitus, and maturity onset diabetes of the young type 4 . 